\title{
RECENZJE
}

\section{Oblicza chrześcijaństwa wschodniego. Ksiega Pamiątkowa Profesora Eugeniusza Iwańca w osiemdziesięciopięciolecie urodzin, red. Stefan Pastuszewski, Krzysztof Snarski, Byd- goszcz: Instytut Wydawniczy „Świadectwo”, 2016, ss. 226. ISBN: 978-83-7456-416-8}

Recenzowany tom jest zbiorem artykułów w formie księgi pamiątkowej na uczczenie osiemdziesiątych piątych urodzin profesora Eugeniusza Iwańca. Profesor Iwaniec jest uznanym badaczem zapomnianej mniejszości religijnej staroobrzędowców (zarówno popowców, jak i bezpopowców), zamieszkałych na dawnych i obecnych ziemiach polskich. Zasłynął monografią staroobrzędowców na ziemiach polskich ${ }^{1}$, całe jego życie naukowe było poświęcone kwestiom staroobrzędowców.

Publikacja podzielona jest na cztery części. W pierwszej części umieszczono tradycyjną w takich pamiątkowych księgach Tabula gratulatoria, w kolejnej opublikowano omówienie dorobku Jubilata, w trzeciej części znaleźć można artykuły i rozprawy dedykowane Jubilatowi, a w ostatniej laudacje i wspomnienia. Jest to zatem różnorodny zbiór prac.

Jako pierwsze omówimy artykuły zgromadzone w drugiej części: Dorobek Jubilata. Ten dział otwiera tekst Krzysztofa Snarskiego Eugeniusz Iwaniec - badacz bistorii i kultury duchowej $i$ materialnej staroobrzedowców. Jest to artykuł biograficzny, przedstawia koleje życia dostojnego Jubilata, jego ścieżkę intelektualnego rozwoju i zainteresowanie się staroobrzędowcami. Henryk Paprocki - w artykule Strażnik tradycji staroobrzedowców (O pracach naukowych profesora Eugeniusza Iwańca) - omawia dorobek naukowy uczonego. Jest to krótkie omówienie wszystkich najważniejszych prac związanych z kwestią staroobrzędowców. Z kolei Michał Głuszkowski w tekście Prace Eugeniusza Iwańca jako inspiracje dla literatów, pokazującym ciekawy aspekt prac naukowych, przypuszcza, że publikacje o staroobrzędowcach mogły stać się inspiracją dla Zbigniewa Nienackiego (Pan Samochodzik i Niewidzialni) oraz Katarzyny Enerlich (Rzeka ludzi osobnych). Na koniec tej części umieszczono sporządzoną przez Krzysztofa Snarskiego bibliografię prac profesora Iwańca, która liczy 49 publikacji, oraz wykaz 31 recenzji i omówień dorobku naukowego.

$1 \quad$ E. Iwaniec, Z driejón staroobrz̨edowców na ziemiach polskich XVII-XX w., Warszawa 1977. 
Trzecią część książki - Artykuly i rozprany dedykowane - zaczynają rozważania Lecha Józefa Kościelaka o publikowaniu źródeł dotyczących mazurskich staroobrzędowców. Zwraca on uwagę na smutny fakt, że opublikowano bardzo mało źródeł na ten temat, więc wciąż istnieją znaczne luki do wypełnienia. Wojciech Lipiński skupił się na historii lipowian, czyli staroobrzędowców z ukraińskiego Budziaku (południowa Besarabia), omawiając w dużym skrócie dzieje tej mniejszości. Jego tekst zawiera bibliografię, jednak brak przypisów źródłowych nie pozwala nam weryfikować wywodów autora. Stefan Pastuszewski z kolei omówił nastawienie Józefa Piłsudskiego do starowierców. Według badań autora Marszałek miał mieć do nich stosunek pozytywny i dzięki temu w okresie międzywojennym, w przeciwieństwie do czasów carskich, mogli się oni swobodnie rozwijać. Joanna Orzechowska opublikowała w księdze artykuł po rosyjsku, w którym omówiła problem obrządku pogrzebowego staroobrzędowców na podstawie księgozbioru klasztoru w Wojnowie: Фрейм-сиенарий похоронныгх и поминальныгх действий старообрядчев (на основе книжной коллекиии Войновского монастьгря). Kolejny artykuł po rosyjsku napisała Helena Pociechina, tym razem poświęcony kwestiom językoznawczym na przykładzie ksiag starowierskich. Daniel Sawicki przedstawił kwestię śpiewu cerkiewnego według liturgicznej reguły Pustelni Wygowskiej. Z kolei Piotr Sawicki zajął się działalnością artystyczną staroobrzędowców pochodzących z Guślic koło Moskwy, którzy stworzyli najżywotniejszy kulturalny ośrodek popowski w Rosji. Pozostając w obszarze historii sztuki, Aleksandra Sulikowska przedstawiła motyw Pana Zastępów na staroobrzędowych ikonach, które znajdują się w Muzeum Narodowym w Warszawie. Jak się okazuje, dla zreformowanej Cerkwi prawosławnej motyw Pana Zastępów był niekanoniczny, więc siłą rzeczy przejęli go starowiercy. Jest to artykuł bogato ilustrowany, zatem pozwala nam prześledzić przemiany tego motywu artystycznego. Artykuł Hanny Kowalskiej-Stus poświęcony jest eschatologicznym i racjonalnym wektorom kultury rosyjskiej, a więc istnieniu i myśleniu. Tekst Na poczatku była Cerkiew Jarosława Makala jest refleksją na temat kilku wybranych słów związanych z Cerkwią. Z kolei Ałła Michajłowna Miasniankina omówiła najnowsze publikacje wschodnioeuropejskie dotyczące starowierców. Antoni Mironowicz przedstawił kolekcję manuskryptów bułgarskich w zbiorach monasteru w Supraślu na podstawie inwentarza z 1557 r. i innych źródeł, dzięki czemu możemy pokusić się o rekonstrukcję monasterskiej librarii, jak również prześledzić rzadko badane relacje kulturalne, związane z wymianą książek, z Serbią i Bułgarią oraz z klasztorem Athos w XVI w. Ostatni artykuł Włodzimierz Wołosiuk poświęcił przemyskiej szkole śpiewu cerkiewnego i jej znaczeniu w XVIII i XIX wieku. Wykazał w nim, że była ona związana z ówczesną próba , ,delatynizacji” 'śpiewów cerkiewnych, opisał też pokrótce działalność kompozytorów z nią związanych: Michała Werbyckiego, Iwana Lawrowskiego i Wiktora Matiuka. Ostatnią część publikacji zajmują, jak już wcześniej wspomniałem, laudacje i wspomnienia. 
Księga jubileuszowa jest pod względem redakcyjnym i wydawniczym dobrze wydana, same zaś artykuły są bardzo zróżnicowane. Publikacja zawiera wiele cennych studiów i przyczynków do dziejów starowierstwa. Jest zatem ciekawą pozycją dla tych, którzy chca poznać historię staroobrzędowców. Z całą pewnością to ważna cegiełka w badaniach nad tym odłamem religijnym prawosławia, który w powszechnej świadomości jest tak mało obecny.

Marcin A. Klemenski 